\title{
Optimization of enterokinase fermentation using a recombinant Saccharomyces cerevisiae
}

\author{
Hyun Jung Kim, Young Hwan Kim, Young Hoon Roh, \\ Baik L. Seong, Chul Soo Shin* \\ Department of Biotechnology, College of Engineering, Yonsei University, 134 Shinchon-dong, \\ Seodaemun-gu, Seoul 120-749, South Korea
}

Received 27 October 2003; received in revised form 8 January 2004; accepted 31 January 2004

\begin{abstract}
The optimization of enterokinase fermentation was performed with a recombinant Saccharomyces cerevisiae. The maximum enterokinase yield and specific yield were obtained when the ratio of yeast extract to bacto peptone was 5:5. However, the fraction of plasmid-containing cells was approximately $65 \%$ for most nitrogen source ratios. From batch cultures, the minimum DOT level was found to be a key factor. Through DO-stat cultivations, the value was further optimized. As the minimum DOT level increased, the product yield and plasmid-containing cell fraction increased, whereas the ethanol concentration decreased. The optimum agitation speed and aeration rate in a 51 jar were determined as $700 \mathrm{rpm}$ and $2 \mathrm{vvm}$, respectively. Under these conditions, a high enterokinase yield of $3.8 \mathrm{mg} / \mathrm{l}$ was obtained with the final ethanol concentration of $0.4 \mathrm{~g} / \mathrm{l}$. The minimum DOT level was maintained to be $60 \%$ or more. Scale-up of enterokinase fermentation from a 51 jar to a 3001 jar was successfully accomplished based on strategies to maintain a constant impeller tip speed and a minimum DOT level at $60 \%$ or more.
\end{abstract}

(c) 2004 Elsevier Ltd. All rights reserved.

Keywords: Enterokinase fermentation; Recombinant Saccharomyces cerevisiae; DO-stat; Scale-up

\section{Introduction}

Enterokinase (enteropeptidase, EC 3.4.21.9) is a membrane-bound serine protease exhibiting a specificity for the sequence of (Asp) ${ }_{4}$-Lys (D4K). The enzyme motif is found in highly conserved amino termini of trypsinogens from a wide range of species [1]. Enterokinase hydrolyzes trypsinogen to trypsin, and activated trypsin stimulates other pancreatic zymogens [2]. Enterokinase is synthesized as a disulphide-linked hetero-dimer with an amino-terminal heavy chain $(120 \mathrm{kDa})$ and a light chain $(47 \mathrm{kDa})$. The light chain $\left(\mathrm{EK}_{\mathrm{L}}\right)$ alone exhibits a proteolytic activity while the heavy chain recognizes macromolecular substrates, such as trypsinogen [3,4]. The crystal structure of enterokinase has been defined [5].

In recent years, enterokinase light chains $\left(\mathrm{EK}_{\mathrm{L}}\right)$ have been widely used to cleave the fusion partner in vitro with a high specificity for (Asp) $)_{4}$-Lys [6]. However, enterokinase can

\footnotetext{
* Corresponding author. Tel.: +82-2-2123-2886; fax: +82-2-362-7265.

E-mail address: csshin@yonsei.ac.kr (C.S. Shin).
}

be obtained only in small quantities from bovine duodenal mucosa, which makes industrial scale production too expensive. Recombinant cells of Escherichia coli [7] or yeast Pichia pastoris [8] encoding bovine $\mathrm{EK}_{\mathrm{L}}$ genes were used in an attempt to solve this problem. However, full-scale optimization of recombinant enterokinase $\left(\mathrm{rEK}_{\mathrm{L}}\right)$ fermentation has not yet been achieved.

Strains of Saccharomyces cerevisiae have been used as a host for production of various eukaryotic proteins $[9,10]$. In fermentations using recombinant cells, control of plasmid stability is particularly important because it directly affects product yield [11-14]. Two stages of continuous cultivation [15-17] and fed-batch processes [18] are used for analysis of plasmid stability.

A recombinant $S$. cerevisiae was constructed to produce C-terminal His-tagged enterokinase for efficient purification and post-cleavage removal [19]. In this study, we investigated key factors for enterokinase fermentations using the recombinant $S$. cerevisiae. Optimum fermentation conditions were determined via batch cultures and DO-stats in 51 jar vessels. A scale-up of batch fermentation from a 51 jar to a 3001 pilot was performed. 


\section{Materials and methods}

\subsection{Microorganism and media}

The expression host organism used in enterokinase fermentation was $S$. cerevisiae 2805 (pep4::HIS3, pro1- $\delta$, can1, Gal2, his3 $\delta$, ura3-52), which was transformed with plasmid pIL20XEK $\mathrm{L}_{\mathrm{L}}-\mathrm{Ca}$-His encoding the C-terminal His-tagged $\mathrm{EK}_{\mathrm{L}}$ [19].

The selective medium for seed culture consisted of $20 \mathrm{~g} / \mathrm{l}$ of glucose, $0.8 \mathrm{~g} / \mathrm{l}$ of complete supplement medium-Ura (Bio101), and $6.7 \mathrm{~g} / \mathrm{l}$ of a yeast nitrogen base without amino acids (DIFCO). The fermentation medium for enterokinase production was composed of $20 \mathrm{~g} / \mathrm{l}$ of glucose, and $10 \mathrm{~g} / \mathrm{l}$ of yeast extract and bacto peptone. The ratios of yeast extract and bacto peptone were varied. A concentrated galactose solution $(200 \mathrm{~g} / \mathrm{l})$ was added as an inducer after $24 \mathrm{~h}$ of cultivation. For measurement of plasmid-containing cells, YM agar medium (DIFCO) and selective agar medium (selective medium plus $20 \mathrm{~g} / \mathrm{l}$ agar) were used.

\subsection{Cultivations}

For optimization of nitrogen sources, seed cultures were performed in $500 \mathrm{ml}$ baffled flasks with $75 \mathrm{ml}$ of sterilized selective medium after inoculation of the recombinant $S$. cerevisiae. Flasks were shaken on a rotary incubator (Jeio Tech, sj-600r) for $24 \mathrm{~h}$ at $30^{\circ} \mathrm{C}$ and $180 \mathrm{rpm}$. Cultivated solutions were added at $5 \%(\mathrm{v} / \mathrm{v})$ as an inoculum to $500 \mathrm{ml}$ baffled flasks with $75 \mathrm{ml}$ of fermentation medium. After $24 \mathrm{~h}$ of cultivation, the galactose solution was added at $2 \%$. Then, mixtures were further cultivated for $24 \mathrm{~h}$ at $30^{\circ} \mathrm{C}$ and $180 \mathrm{rpm}$.

For fermentations in a 51 jar, seed cultures were prepared in $500 \mathrm{ml}$ baffled flasks in the same manner as for flask fermentations. Cultivated solutions were added at $5 \%(\mathrm{v} / \mathrm{v})$ to the 51 jars (KoBioTech Co., Ltd.) containing 31 of fermentation medium. Then, the mixtures were cultivated at $30^{\circ} \mathrm{C}$ and $500 \mathrm{rpm}$ with an aeration rate of $0.5-2.0 \mathrm{vvm}$. After $24 \mathrm{~h}$, the concentrated galactose solution was added at $2 \%$, and then further cultivated for $24 \mathrm{~h}$.

DO-stat fermentations in 51 jars were performed in the same manner as in a 51 jar. The DOTs in fermenters were maintained at a constant level during cultivation by control of the aeration rate and agitation speed.

For the fermentation scale-up to a 301 jar (KoBioTech Co., Ltd.), seed cultures were prepared twice. The first culture was prepared in a $500 \mathrm{ml}$ baffled flask in the same manner as described previously. For the second seed culture, the cultivated solution was added at $5 \%(\mathrm{v} / \mathrm{v})$ to a 51 jar containing 31 of selective medium. Then, the mixture was cultivated for $24 \mathrm{~h}$ at $30^{\circ} \mathrm{C}$ with an agitation speed of $500 \mathrm{rpm}$ and an aeration rate of $2.0 \mathrm{vvm}$. The cultivated solution was added at $5 \%(\mathrm{v} / \mathrm{v})$ to the 301 jar containing 201 of fermentation medium, followed by cultivation for $24 \mathrm{~h}$ at $30^{\circ} \mathrm{C}$ with an agitation speed of $460 \mathrm{rpm}$ and an aeration rate of $2 \mathrm{vvm}$.
Then, the galactose solution was added and the mixture was further cultivated.

For the pilot-scale fermentation, the first and second seed cultures were prepared in the same manner as described previously. The third seed culture was made in a 301 jar containing 201 of selective medium under the same condition as for a 51 jar. The pilot fermentation was conducted in a 3001 jar (KoBioTech Co., Ltd.) containing 2001 of fermentation medium at $30^{\circ} \mathrm{C}$ with an agitation speed of $150 \mathrm{rpm}$ and an aeration rate of $2 \mathrm{vvm}$.

\subsection{Measurement of cell concentrations and plasmid-containing cells}

For measurement of cell concentrations, cell precipitates were isolated by centrifugation of culture broths (Vision Scientific, VS-15000, angle type, 4,000 × $g$, $5 \mathrm{~min}$ ). After cells were suspended in a $0.9 \%(\mathrm{w} / \mathrm{v})$ saline solution, the absorbance of the solution was measured at $600 \mathrm{~nm}$ on a spectrophotometer (Shimadzu, UV-1201) and values were converted to dry cell weight.

For measurement of plasmid-containing cells, after the cell precipitates were suspended in a saline solution, the solution was spread on plates with either a selective agar medium or a YM agar medium. After $24 \mathrm{~h}$ of incubation at $30{ }^{\circ} \mathrm{C}$, the fractions of plasmid-containing cells vs. total cells were estimated from the number ratios of cells grown on the two types of media.

\subsection{Measurement of enterokinase activity}

Enterokinase activities were measured by a fluorometric assay using the synthetic substrate Gly-(Asp) 4 -Lys- $\beta$ naphthylamide [20]. One milliliter of fluorogenic substrate (0.5 mM GD4K-NA, $25 \mathrm{mM}$ Tris- $\mathrm{HCl}$ at $\mathrm{pH} 8.4,10 \mathrm{mM}$ $\mathrm{CaCl}_{2}$, and $10 \%$ DMSO) was mixed with $0.2 \mathrm{ml}$ of enzyme broth (temporarily stored in a $50 \%$ glycerine solution). Then, the solutions were incubated for $5 \mathrm{~min}$ in a fluorescence spectrophotometer (Varian, FC-8000) at $37^{\circ} \mathrm{C}$. Enzyme activities were calculated as fluorescence differences versus time with excitation at $337 \mathrm{~nm}$ and emission at $420 \mathrm{~nm}$. The enzymic activities were converted into mass per unit volume values of culture broth.

\subsection{Measurement of glucose, galactose, and ethanol contents}

For measurement of glucose, galactose and ethanol contents, the supernatants were obtained by centrifugation (Vision Centrifuge VS-15000, angle type, 4,000 $\times g$ ) of culture broths. Concentrations were then measured on a Bio-LC (Dionex, DX-500) equipped with an analytical PA-1 column (Dionex, CarboPac, $4 \mathrm{~mm} \times 250 \mathrm{~mm}$ ), a gradient pump (Dionex, GP 40) and an electrochemical detector (Dionex, ED 40). A mixture (16:84) of a $50 \mathrm{mM} \mathrm{NaOH}$ solution and 
distilled water at $30^{\circ} \mathrm{C}$ was eluted at $5 \mathrm{ml} / \mathrm{min}$ as an isocratic mobile phase.

\subsection{Measurement of DOT and $\mathrm{pH}$}

Dissolved oxygen tensions (DOTs) were measured on a DO-analyzer (KoBioTech Co., Ltd., LA-150). The pH values of culture broths were monitored using a pH-meter (KoBioTech Co., Ltd.).

\subsection{Chemicals}

All chemicals used were of reagent-grade and were purchased from Duksan, Sigma, and Difco. Complete supplement medium-Ura (CSM-Ura) was a product of Bio101 Co.

\section{Results and discussion}

Key fermentation factors were sought from medium compositions and cultivation conditions for efficient enterokinase production using a recombinant $S$. cerevisiae. Batch fermentations were carried out at two stages of growth and production in a flask or a fermenter. Since glucose has been reported as the key carbon source in the growth stage and the galactose in production stage by the developers of the microorganism strain used [19], the carbon sources were not further optimized.

\subsection{Optimum nitrogen concentrations of fermentation medium}

Cultivations were conducted for $24 \mathrm{~h}$ (growth stage) in $500 \mathrm{ml}$ baffled flasks containing the fermentation medium. The galactose solution was then added to the flasks at $2 \%$ followed by $24 \mathrm{~h}$ of further cultivation in the production stage (Fig. 1).

From our preliminary analysis, yeast extract and bacto peptone were found to be the key nitrogen sources for fer-

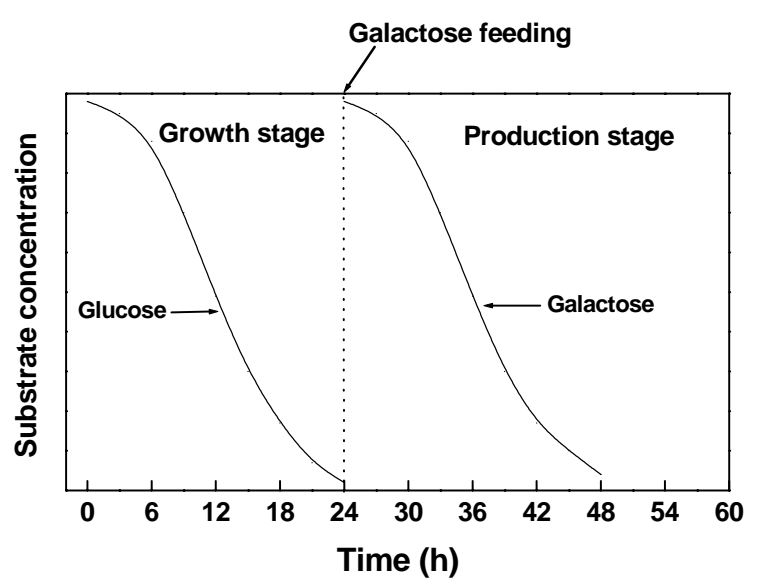

Fig. 1. A schematic diagram of enterokinase fermentations.
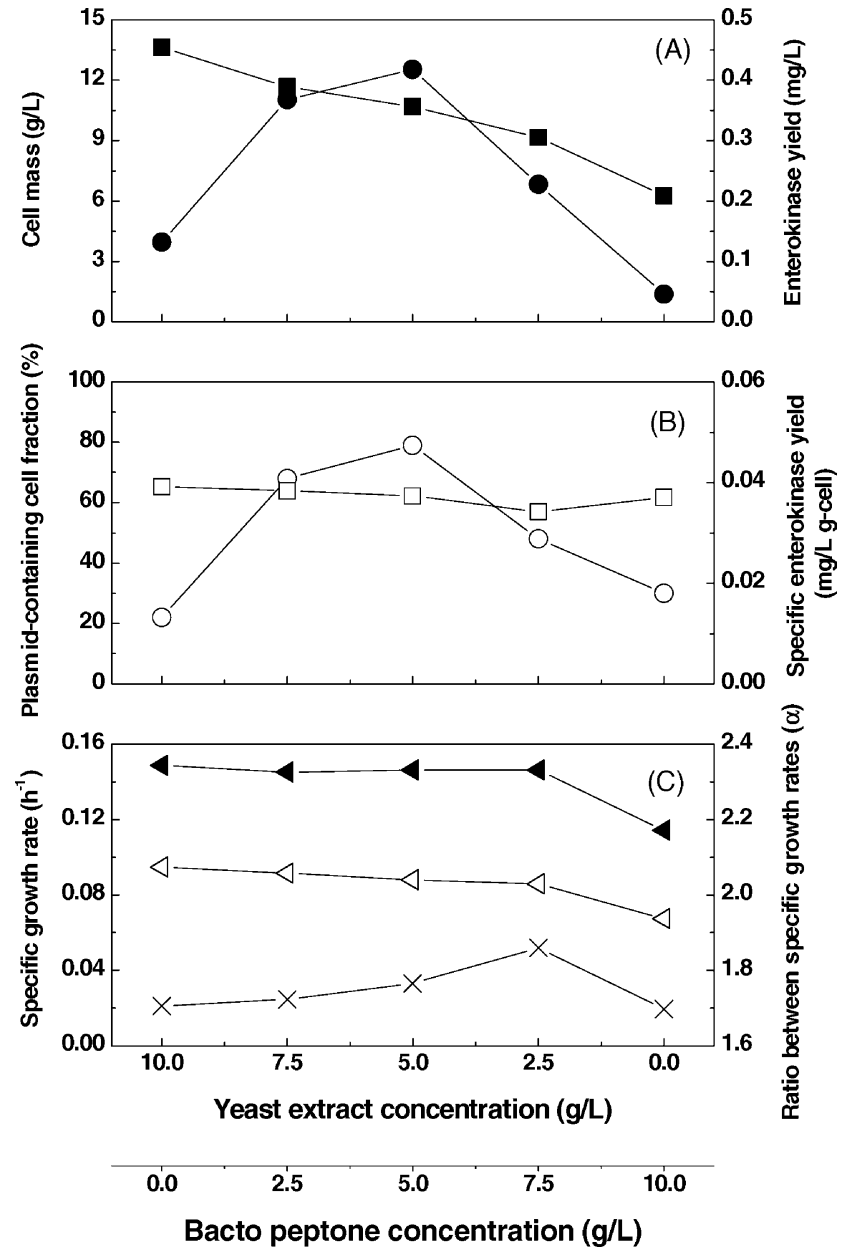

Fig. 2. Cell mass and enterokinase yield at the end of cultivation depending on the combination ratios of yeast extract to bacto peptone in baffled flasks. The total content of yeast extract and bacto peptone was fixed at $10 \mathrm{~g} / \mathrm{l}$. Cultivations were performed in a $500 \mathrm{ml}$ baffled flask at $30^{\circ} \mathrm{C}$ and $180 \mathrm{rpm}$ for $48 \mathrm{~h}$. (O) Enterokinase yield; ( $\mathbf{\square}$ ) cell mass; (○) specific enterokinase yield; $\square$ ) plasmid-containing cell fraction; (४) specific growth rate of plasmid-free cells; $(\triangleleft)$ specific growth rate of plasmid-containing cells; $(\times)$ ratio of the specific growth rates of plasmid-free and plasmid-containing cells.

mentation. Here, therefore, the optimum combination of yeast extract and bacto peptone concentrations in the fermentation medium was determined. The total nitrogen source content in culture medium was fixed at $10 \mathrm{~g} / \mathrm{l}$ whereas the ratio of yeast extract to bacto peptone was varied from 0:10 to 10:0. Cell growth was enhanced with an increasing ratio of yeast extract to bacto peptone (Fig. 2A), whereas a maximum enterokinase yield of $0.49 \mathrm{mg} / \mathrm{l}$ was obtained at a 5:5 ratio. Yeast extract was a good component for cell growth whereas bacto peptone was important for enhancement of the enterokinase yield. There are two general strategies for increasing productivity. One is to use high cell density cultures while the other is to maintain high cell activities for production. The specific enterokinase yields had a pattern similar to the overall yields (Fig. 2B). The maximum specific enzyme yield was $0.045 \mathrm{mg} / \mathrm{l}$ of g-cell at a 5:5 ratio, in- 


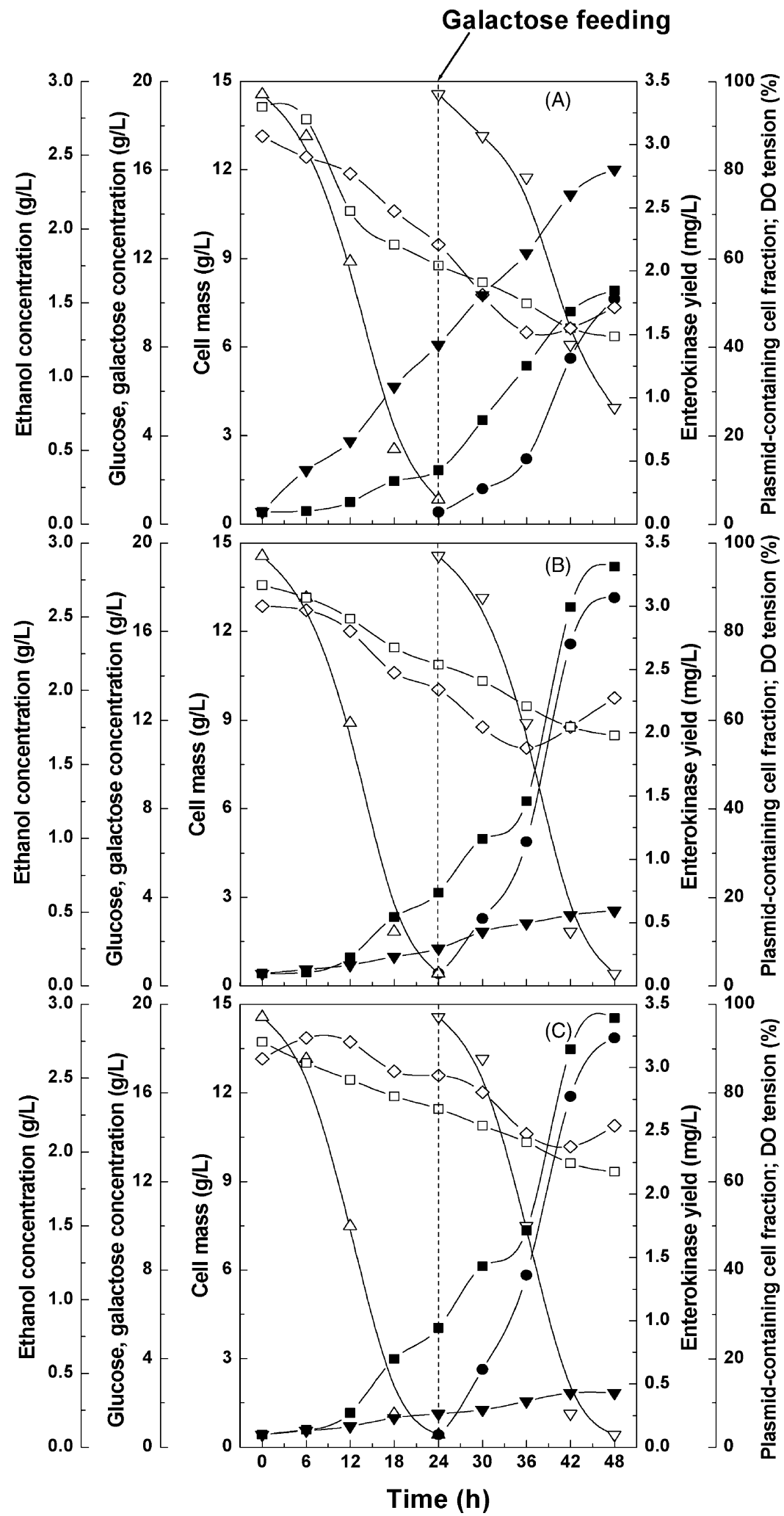

Fig. 3. Patterns of enterokinase fermentation at an aeration rate of: (A) $0.5 \mathrm{vvm}$, (B) $1.0 \mathrm{vvm}$ or (C) $2.0 \mathrm{vvm}$ in a 51 jar. Cultivations were performed for $48 \mathrm{~h}$ at $30^{\circ} \mathrm{C}$ and $500 \mathrm{rpm}$. $(\boldsymbol{O})$ Enterokinase yield; $(\boldsymbol{\square})$ cell mass; $(\boldsymbol{\nabla})$ ethanol concentration; $(\triangle)$ glucose concentration; $(\nabla)$ galactose concentration; $(\diamond)$ DO tension; $(\square)$ plasmid-containing cell fraction. 
dicating that a good strategy is to obtain a high product yield by enhancement of cell activity rather than by enhanced cell growth.

One of the key factors in fermentations using recombinant cells is to maintain high fractions of plasmid-containing cells. Whether the plasmids do or do not exist inside the host cells can directly affect the overall yield. The product yield in a large scale fermentation can be seriously reduced with an increasing fraction of plasmid-free cells due to repeated transfers. Preliminary analyses showed that the fraction of plasmid-free cells increased significantly with an increasing generation of host cells. The fractions of plasmid-containing cells were estimated (Fig. 2B). The plasmid stabilities of cells were maintained at a constant level regardless of the combination ratios of yeast extract and bacto peptone concentrations. The fraction of plasmid-containing cells was approximately $65 \%$ for most nitrogen source ratios. However, enterokinase yields were severely affected by different combinations of the two nitrogen sources. The growth rates of plasmid-containing and plasmid-free cells were estimated. The specific growth rate of plasmid-free cells $\left(\mu^{-}\right)$ was higher than the growth rate of plasmid-containing cells $\left(\mu^{+}\right)$(Fig. 2C) probably due to spending of extra metabolic energy for plasmid DNA in non-selection media [21]. $\mu^{-}$ values of approximately $0.157 \mathrm{~h}^{-1}$ were obtained at most ratios of yeast extract to bacto peptone, whereas $\mu^{+}$values were reduced in a range of $0.084-0.094 \mathrm{~h}^{-1}$. At a ratio of $0: 10$ the values of $\mu^{+}$and $\mu^{-}$were seriously decreased. The ratio $(\alpha)$ between the specific growth rates of plasmid-free and plasmid-containing cells can be expressed as follows:

$\alpha=\frac{\mu^{-}}{\mu^{+}}$

As shown in Fig. 2C, the $\alpha$ value increased gradually from 1.69 to 1.87 with varying $\mathrm{N}$-source ratios from 10:0 to 2.5:7.5. However, the value decreased sharply to 1.68 at a ratio of $0: 10$. The highest $\alpha$ value was obtained at a ratio of 2.5:7.5, while the maximum productivity was achieved at a ratio of 5:5.

\subsection{Batch fermentation patterns at various aeration rates}

Enterokinase fermentations were performed in 51 jars containing $5 \mathrm{~g} / \mathrm{l}$ of yeast extract and $5 \mathrm{~g} / \mathrm{l}$ of bacto peptone. Galactose was added at $24 \mathrm{~h}$ of cultivation. The aeration rate in 51 batch cultures was varied in a range of $0.5-2.0 \mathrm{vvm}$ and the optimum condition for enzyme production was determined.

At an aeration rate of $0.5 \mathrm{vvm}$, a low enterokinase yield of $1.8 \mathrm{mg} / \mathrm{l}$ was attained at the end of cultivation with a high ethanol level of $2.3 \mathrm{~g} / 1$ (Fig. 3A). With rapid cell growth, the DOT decreased to $40 \%$ and the fraction of plasmid-containing cells was significantly lowered to $40 \%$. Low DOT levels probably cause excessive accumulation of ethanol, resulting in poor growth and low product yields. However, when the fermenter aeration rate was raised to
$1.0 \mathrm{vvm}$, the DOT was maintained at $50 \%$ or more, with an enzyme yield of $3.0 \mathrm{mg} / \mathrm{l}$ (Fig. 3B). The final ethanol concentration was $0.5 \mathrm{~g} / \mathrm{l}$, and the fraction of plasmid-containing cells was maintained at more than 55\%. A high enterokinase yield was achieved with a low level of ethanol in the culture broth due to a sufficient air supply. On the other hand, when the aeration rate was increased to $2.0 \mathrm{vvm}$, the enterokinase yield and the cell concentration at the end of cultivation increased to $3.2 \mathrm{mg} / \mathrm{l}$ and $14.5 \mathrm{~g} / \mathrm{l}$, respectively (Fig. 3C). The final ethanol concentration was $0.4 \mathrm{~g} / \mathrm{l}$, and the fraction of plasmid-containing cells was maintained at $60 \%$ or more. The minimum DOT was $65 \%$. Ethanol production can be suppressed directly by maintenance of high DOTs, leading to increases of cell concentrations, plasmid-containing cell fraction, and enzyme yield.

\subsection{Determination of the minimum DOT level using DO-stats}

DO-stat fermentations were performed in 51 jars to analyze the effect of DOT on enterokinase production. The DOT in a fermenter was maintained at a constant level during cultivation by control of the aeration rate and the agitation speed. As shown in Fig. 4, with a 20\% DOT-stat an enterokinase yield of approximately $1.4 \mathrm{mg} / \mathrm{l}$ was obtained. However, as the DO-stat level was raised to $70 \%$, the enzyme yield increased to $3.4 \mathrm{mg} / \mathrm{l}$. The fraction of plasmid-containing cells also increased from 37 to $65 \%$ whereas the ethanol yield decreased from 2.5 to $0.4 \mathrm{~g} / \mathrm{l}$. Plasmid stability and enzyme yield apparently depend on the ethanol level in the culture broth. Therefore, the DOT level in a fermenter should be maintained at more than $60 \%$ for efficient enterokinase production.

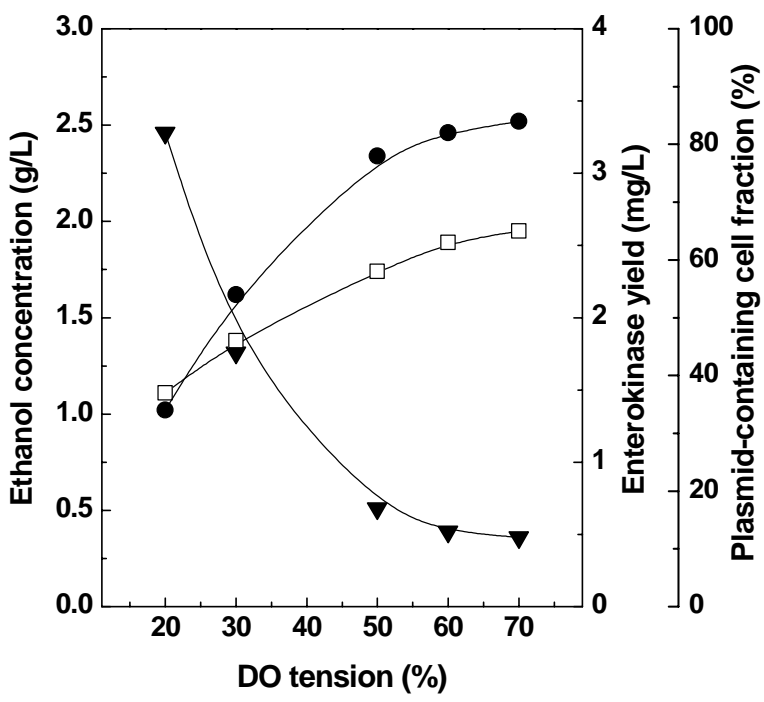

Fig. 4. Patterns of enterokinase fermentation with various DO-stats in 51 jars. The DOT values were adjusted in a range of $20-70 \%$ by control of the aeration rate and the agitation speed. Cultivations were performed for for $48 \mathrm{~h}$ at $30^{\circ} \mathrm{C}$. ( $)$ Enterokinase yield; $(\boldsymbol{\nabla})$ ethanol concentration; $(\square)$ plasmid-containing cell fraction. 
Table 1

Optimized enterokinase fermentations from a 51 to a 3001 jars

\begin{tabular}{lcrc}
\hline & \multicolumn{3}{l}{ Fermenters } \\
\cline { 2 - 4 } & 51 & 301 & 3001 \\
\hline Agitation speed (rpm) & 700 & 460 & 150 \\
Minimum DOT level (\%) & 69 & 65 & 60 \\
Final enterokinase yield (mg/l) & 3.8 & 3.7 & 3.5 \\
\hline
\end{tabular}

Cultivations were performed for $60 \mathrm{~h}$ at $30^{\circ} \mathrm{C}$ with an aeration rate of 2 vvm, respectively.

From additional analyses in a 51 jar fermenter, the optimum agitation speed for maintenance of $60 \%$ DOT or more was determined to be $700 \mathrm{rpm}$ with an aeration rate of $2.0 \mathrm{vvm}$.

\subsection{Scale-up from a $5 \mathrm{l}$ to $300 \mathrm{l}$ pilot}

A fermentation scale-up of a 51 jar to a 3001 pilot was performed. A constant impeller tip speed was used as a scale-up factor. Based on this criterion, an impeller rotational speed of $700 \mathrm{rpm}$ in a 51 fermenter corresponded to $460 \mathrm{rpm}$ in a 301 jar and $150 \mathrm{rpm}$ in a 3001 pilot. The results obtained from $60 \mathrm{~h}$ of cultivations in the fermenters were summarized in Table 1. The DOT levels in a 301 jar and a pilot were maintained at $60 \%$ or more throughout the cultures. The enterokinase yields reached approximately $3.7 \mathrm{mg} / \mathrm{l}$ in a 301 , and $3.5 \mathrm{mg} / \mathrm{l}$ in a 3001 jars, respectively, indicating a successful scale-up.

\section{Conclusions}

Similar plasmid-containing cell fractions were obtained regardless of the ratio of yeast extract to bacto peptone. The specific enterokinase yield depended on this ratio, indicating that the ratio can affect the amount of enzyme formation. The average specific growth rate of plasmid-free cells was higher than the growth rate of plasmid-containing cells, indicating that the number of plasmid-free cells can be increased by repeated transfers, resulting in low product yields.

The DOT level in a fermenter apparently directly affects ethanol production. When an excessive amount of ethanol accumulates in the culture broth, the fraction of plasmid-containing cells is reduced, leading to a low product yield. Therefore, the DOT should be maintained at high levels in order to suppress ethanol accumulation. Based on strategies to maintain a constant impeller tip speed and a minimum DOT, a scale-up of enterokinase fermentation from a 51 jar to a 3001 pilot was successfully accomplished.

\section{Acknowledgements}

This research was supported by a fund on clean project from Ministry of Commerce, Industry and Energy (1999-2001).

\section{References}

[1] Pavlov IP. The work of the digestive glands. Charles Griffin \& Co. London: W.H. Thompson; 1902.

[2] Bricteux-Grégoire S, Schyns R, Florkin M. Phylogeny of trypsinogen activation peptides. Comp Biochem Phys B 1972;42:23-39.

[3] Hofer R, Steidl-Schennach D. Characterization of a trypsin-like enzyme in the duodenal mucosa of urodela and its significance for the activation of pancreatic zymogens. Comp Biochem Phys B 1978;61:459-61.

[4] Lu D, Yuan X, Zheng X, Sadler E. Bovine proenteropeptidase is activated by trypsin, and the specificity of enteropeptidase depends on the heavy chain. J Biol Chem 1997;272:31293-300.

[5] Lu D, Fütterer K, Korolev S, Zheng X, Tan K, Waksman G, et al. Crystal structure of enteropeptidase light chain complexed with an analog of the trypsinogen activation peptide. J Mol Biol 1999;292:361-73.

[6] Light A, Fonseca P. The preparation and properties of the catalytic subunit of bovine enterokinase. J Biol Chem 1984;259:13195-8.

[7] Collins-Racie LA, McColgan JM, Grant KL, DiBlasio-Smith EA, McCoy JM, LaVallie ER. Production of recombinant bovine enterokinase catalytic subunit in Escherichia coli using the novel secretory fusion partner DsbA. Biotechnology 1995;13:982-7.

[8] Vozza LA, Wittwer L, Higgins DR, Purcell TJ, Bergseid M, Collins-Racie LA, et al. Production of a recombinant bovine enterokinase catalytic subunit in the methylotrophic yeast Pichia pastoris. Biotechnology 1996;14:77-81.

[9] Cereghino GPL, Cereghino JL, Ilgen C, Cregg JM. Production of recombinant proteins in fermenter cultures of the yeast Pichia pastoris. Curr Opin Biotechnol 2002;13:329-32.

[10] Napp SJ, Da Silva NA. Enhanced productivity through gratuitous induction in recombinant yeast fermentations. Biotechnol Prog 1994;10:125-8.

[11] Caunt P, Impoolsup A, Greenfield PF. Stability of recombinant plasmids in yeast. J Biotechnol 1988;8:173-92.

[12] Zhang Z, Moo-Young M, Chisti Y. Plasmid stability in recombinant Saccharomyces cerevisiae. Biotechnol Adv 1996;14:401-35.

[13] Zhang Z, Scharer JM, Moo-Young M. Plasmid instability kinetics in continuous culture of a recombinant Saccharomyces cerevisiae in airlift bioreactor. J Biotechnol 1997;55:31-41.

[14] Grabherr R, Nilsson E, Striendner G, Bayer K. Stabilizing plasmid copy number to improve recombinant protein production. Biotechnol Bioeng 2002;77:142-7.

[15] Curless C, Fu K, Swank R, Menjares A, Fieschko J, Tsai L. Design and evaluation of a two-stage, cyclic, recombinant fermentation process. Biotechnol Bioeng 1991;38:1082-90.

[16] Gupta JC, Pandey G, Mukherjee KJ. Two-stage cultivation of recombinant Saccharomyces cerevisiae to enhance plasmid stability under non-selective conditions: experimental study and modeling. Enzyme Microb Technol 2001;28:89-99.

[17] Gupta JC, Mukherjee KJ. Stable maintenance of plasmid in continuous culture of yeast under non-selective conditions. J Biosci Bioeng 2001;92:317-23.

[18] Cheng C, Huang YL, Yang S. A novel feeding strategy for enhanced plasmid stability and protein production in recombinant yeast fedbatch fermentation. Biotechnol Bioeng 1997;56:23-31.

[19] Choi SI, Song HW, Moon JW, Seong BL. Recombinant enterokinase light chain with affinity tag: Expression from Saccharomyces cerevisiae and its utilities in fusion protein technology. Biotechnol Bioeng 2001;75:718-24.

[20] Hermon-Taylor J. Hydrolysis of artificial substrates by enterokinase and trypsin and the development of a sensitive specific assay for enterokinase in serum. Biochim Biophys Acta 1979;567:20715.

[21] Doran PM. Bioprocess engineering principles. San Diego: Academic Press; 1995. p. 279-81. 